\title{
Zooplankton as a transitional host for Escherichia coli in freshwater
}

Andrea di Cesare ${ }^{1}$, Francesco Riva ${ }^{2}$, Noemi Colinas ${ }^{1,3}$, Giulia Borgomaneiro ${ }^{1}$, Sara Borin ${ }^{2}$, Pedro J. CabelloYeves $^{4}$, Claudia Canale ${ }^{5}$, Nicholas Cedraro ${ }^{6}$, Barbara Citterio ${ }^{7}$, Elena Crotti ${ }^{2}$, Gianmarco Mangiaterra ${ }^{6}$, Francesca Mapelli ${ }^{2}$, Vincenzo Mondino ${ }^{8}$, Carla Vignaroli ${ }^{7}$, Walter Quaranta ${ }^{1,7}$, Gianluca Corno ${ }^{1}$, Diego Fontaneto $^{1}$, Ester M Eckert ${ }^{1^{*}}$

1 Molecular Ecology Group (MEG), National Research Council of Italy - Water Research Institute (CNR-IRSA) Verbania, Italy

2 Department of Food, Environmental and Nutritional Sciences (DeFENS), University of Milan, Milan, Italy 3 Institut Cavanilles de Biodiversitat i Biologia Evolutiva, Universitat de València, Valencia, Spain

4 Evolutionary Genomics Group, Departamento de Producción Vegetal y Microbiología, Universidad Miguel, Hernández, San Juan de Alicante, Alicante, Spain

5 Microbiology Lab, ASL-VCO Castelli Hospital, Via Fiume 18, Verbania

6 Department of Life and Environmental Sciences, Polytechnic University of Marche, via Brecce Bianche, 60131, Ancona, Italy

7 Department of Biomolecular Sciences, sect. Biotechnology, University of Urbino "Carlo Bo", Italy

8 Tropical and Infectious Diseases Unit, ASL-VCO Castelli Hospital, Via Fiume 18, Verbania

*author to whom correspondence should be addressed: Ester M Eckert, CNR-IRSA, +390323518321 estermaria.eckert@cnr.it

\section{Abstract}

This study shows that Escherichia coli can be temporarily enriched in zooplankton in natural conditions and that these bacteria can belong to different phylogroups and sequence types including environmental as well as clinical and animal isolates. We isolated $10 \mathrm{E}$. coli strains and sequenced the genomes of two of them. Phylogenetically the two isolates were closer to strains isolated from poultry meat than with freshwater $\mathrm{E}$. coli, albeit their genomes were smaller than those from poultry. After isolation and fluorescent protein tagging of strains ED1 and ED157 we show that Daphnia sp. can take up these strains and release them alive again, thus forming a temporary host for $\mathrm{E}$. coli. In a chemostat experiment we show that the association does not prolong the bacterial long-term survival, but that at low abundances it does also not significantly reduce the bacterial numbers. We demonstrate that $\mathrm{E}$. coli does not belong to the core microbiota of Daphnia, suffers from competition by the natural microbiota of Daphnia, but can profit from its carapax to survive in water. All in all, this study suggests that the association of $\mathrm{E}$. coli to Daphnia is only temporary but that the cells are viable therein and this might allow encounters with other bacteria for genetic exchange and potential genomic adaptations to the freshwater environment.

\section{Importance}

The contamination of freshwaters with faecal derived bacteria is of major concern regarding drinking water acquisition and recreational activities. Ecological interactions promoting their persistence are still very scarcely studied. This study, which analyses the survival of $\mathrm{E}$. coli in the presence of zooplankton, is thus of ecological as well as water safety relevance. 


\section{Introduction}

Faecal bacteria can enter aquatic environments by different routes, e.g., sewage discharge or direct faecal deposition (Korajkic, et al. 2019). Although faecal bacteria are tendentially seen to rapidly drop in abundance once outside host, some aquatic environments might allow their long-term survival or growth (Korajkic, et al. 2019). Escherichia coli is one of the predominant species forming the microbial community that shapes the commensal gut of vertebrates (Martinson and Walk 2020). Thus it is commonly released, by faecal route, into aquatic environments (Espinosa-Urgel and Kolter 1998), and it is therefore used as a faecal indicator bacterium (FIB) to evaluate anthropogenic water pollution (Jang, et al. 2017). Clinically relevant E. coli strains (Vignaroli, et al. 2013; Jørgensen, et al. 2017), including antibiotic resistant isolates (Vignaroli, et al. 2012; Baniga, et al. 2020; Fernandes, et al. 2020), can be found in waters. Moreover, there is evidence that $E$. coli can adapt to a freshwater lifestyle shown for example through differential gene expression once incubated in water (Espinosa-Urgel and Kolter 1998).

Naturalized E. coli, e.g. E. coli that entered the aquatic environment from the gut and then adapted to this lifestyle, were isolated from lake sediments and phytoplankton and different studies showed the capability of this species to genetically adapt and persist in the environment for example through encapsulation (Power, et al. 2005; Ishii, Ksoll, et al. 2006; Ishii, Yan, et al. 2006; Walk, et al. 2007). Several E. coli isolated from freshwaters had a small genome size and other peculiarities at the genomic level that suggested an evolutionary adaptation to this habitat (Touchon, et al. 2020). This is particularly interesting since genome reduction has been proposed repeatedly as an adaptation to aquatic environments in common environmental bacteria (Grote, et al. 2012; Salcher, et al. 2019) and in experimental systems (Lee and Marx 2012; Baumgartner, et al. 2017). Thus, the aquatic environment may contribute to the genetic evolution of E. coli (Touchon, et al. 2020).

However, mammal associated faecal bacteria usually persist badly in cold habitats, such as deep lakes. Particularly, pelagic cold waters are a very hostile environment for such gut symbionts. If they are not grazed by flagellated predators upon arrival, they are surely not favoured by resource competition (González, et al. 1992; Wanjugi and Harwood 2013; Eckert, et al. 2019). Since evolution, as seen in the genome reduction of $E$. coli (Touchnon, et al. 2020), takes time, a certain long-term persistence of vertebrate commensal strains in the aquatic habitat is crucial, and the question remains: In which niche does persistence take place? In clinical settings these bacteria thrive better in biofilms (Costerton, et al. 1999) and they might persist in a similar niche in aquatic habitats (Hall-Stoodley and Stoodley 2005; Eckert, et al. 2018). In lake environment biofilms can be formed on dead organic and inorganic material, sediments and stones or animals, and FIB have been found in sediments (Haller, et al. 2009; John, et al. 2009), macrophytes (Quero, et al. 2015) and on fish (Declerck, et al. 2007; Abgottspon, et al. 2014) for example. Much less attention has been devoted to small invertebrates, i.e. zooplankton, as a potential host for such bacteria. Such animals are interesting since their microbiota seems to be composed by many transient microbes and thus likely more prone to be invaded by allochthonous bacteria (Grossart, et al. 2010; Hammer, et al. 2019; Callens, et al. 2020; Eckert, et al. 2021). In fact, antibiotic resistant bacteria were easily removed from the surrounding water in a laboratory experiment but persisted in the crustacean Daphnia obtusa (Eckert, et al. 2016) and FIB have even been shown to even exchange genetic material in Daphnia pulex (Olanrewaju, et al. 2019). It is generally assumed that the presence of Daphnia sp. reduces $E$. coli abundance in the water (Burnet, et al. 2017; Ismail, et al. 2019). Nevertheless, in a study based on $16 \mathrm{~S}$ rRNA gene amplicon sequencing from a lake $E$. coli/Shigella made up for a large percentage of the copepod and Daphnia microbiota, but was present only with low abundances on stones, water and sediments (Eckert, et al. 2020). In the present study we thus wanted to investigate the nature of the relationship between E. coli and Daphnia in the freshwater environment to clarify the possible role that Daphnia might have on the persistence of $E$. coli in waters from an ecological point of view.

Here we tested the hypothesis that an association with zooplankton animals of the genus Daphnia could help a FIB, E. coli, to survive in the harsh conditions of a freshwater lake. It was shown that the presence of Daphnia pulex in a few hours reduced the abundance of surrounding E. coli (Burnet, et al. 2017) but here we were interested in the longer-term association of the bacteria with the animal under 
natural conditions. Our hypothesis is that such association might help the bacterium to adapt to this environment, leading to evolution in its genome. Therefore, we quantified uidA, an indicator gene of $E$. coli, in DNA extracted from various potential niches for FIB from a freshwater lake, including stone biofilms, zooplankton, sediment and compared it to the pelagic water. Moreover, we searched for the occurrence of $E$. coli related $16 \mathrm{~S}$ rRNA reads in a large dataset of zooplankton associated microbiota. We then isolated $E$. coli strains from a Daphnia host, genotyped them and tagged two of the strains with fluorescent proteins and sequenced their genome. This allowed us to conduct experiments on the association of these strains with an invertebrate host. Our hypothesis was that despite Daphnia grazing would reduce the abundance of $E$. coli in the water it would still allow for a better survival of the FIB over a longer time thanks to a shortterm refuge of part of the population within its gut. Moreover, we speculate that such an association might in a long term help E. coli to adapt to freshwater over physiological and/or genetic adaptations. 


\section{$2.1 \mathrm{E}$. coli abundance in zooplankton microbiomes}

Initially, we observed a large number of E. coli/Shigella related reads in our Illumina MiSeq dataset of zooplankton (Daphnia gr. galeata/longispina and copepod) associated microbiota obtained from Lake Maggiore (Eckert, et al. 2020). In order to confirm the presence of E. coli, quantitative PCR (qPCR) assays were conducted using $E$. coli specific primers for the uidA gene (1-CAATGGTGATGTCAGCGTT and 2ACACTCTGTCCGGCTTTTG, (Srinivasan, et al. 2011)) using the RT-thermocycler CFX Connect (Bio-Rad). The standard calibration curve for the quantification of uidA was carried out as described elsewhere (Sabatino, et al. 2015) and the gene concentration was expressed as gene copy/Daphnia or $\mathrm{mL}$ of water. The same was done for Daphnia obtusa isolated from a small pond in the garden of CNR-IRSA (Eckert, et al. 2016). Twenty individuals were washed in autoclaved MilliQ water, recollected per triplicate and introduced in DNA Isolation Kit in Ultra Clean Microbial or Power Soil DNA Isolation Kit (Qiagen) for DNA extraction. The right size of all qPCR products was evaluated by electrophoresis ( $30 \mathrm{~min}$ at $80 \mathrm{~V}, 1 \%$ agarose gel). The efficiency of reaction was $87.5 \%$ and $R^{2}$ was 0.99 . The limit of quantification (LOQ) was determined (Bustin, et al. 2009) and was 45 gene copy/ $\mu \mathrm{L}$.

Furthermore, we checked a large dataset of microbial communities associated with zooplankton, from many natural freshwater habitats and cultures published elsewhere (Eckert, et al. 2021) looking for the presence of E. coli/Shigella affiliated reads. The dataset is composed of cladocerans (Daphnia magna, Daphnia obtusa, Diaphanosoma brachyurum, Simocephalus sp. and Mesocyclops leukarti) and rotifers (Adineta vaga, Keratella serrulata, Lecane elsa, Lecane inermis, Epiphanes senta, Keratella quadrata and Polyarthra sp.) (see also Figure 2).

\subsection{E. coli isolates}

\subsubsection{Isolation}

Individuals of Daphnia obtusa were collected two or three times per week between May to July and October to November, from a rainwater-fed pond in the garden of the CNR-IRSA in Verbania (Italy). Thirty individuals of Daphnia obtusa were washed in autoclaved MilliQ water (Millipore), crushed and sonicated ( 3 times, 1 minute each cycle with vortex within cycles) in $1 \mathrm{ml}$ of physiological solution. Serial ten-fold dilutions were performed (from 1:10 to $1: 10^{6}$ ). $1 \mathrm{ml}$ of each dilution was filtered onto nitrocellulose membrane filters (type GSWP, $25 \mathrm{~mm}$ diameter, $0.22 \mu \mathrm{m}$ pore size, Millipore) and filters were plated onto $\mathrm{mFC}$ agar plates (Biolife) and incubated for $48 \mathrm{~h}$ at $37^{\circ} \mathrm{C}$.

\subsubsection{Identification and genetic characterization of $\mathrm{E}$. coli isolates}

Aliquots of presumptive E. coli colonies were introduced in $1 \mathrm{~mL}$ of physiological solution, centrifuged (5000 rcf, 4으, for 10 minutes), boiled for 15 minutes, frozen for 2-4 hours and centrifuged as before. DNA from presumptive E. coli colonies and from Daphnia were tested for the presence of the uidA gene using the primers above mentioned by PCR. Conditions for the PCR assays were: $5 \mu$ l of Buffer $5 X, 0.5 \mu \mathrm{l}$ dNTPs (10 $\mathrm{mM}), 0.2 \mu \mathrm{l}$ Taq-polimerase $(5 \mathrm{U} / \mu \mathrm{l}), 0.25 \mu \mathrm{l}$ per each primers $(100 \mu \mathrm{M})$, and water that it was added to arrive to final volume of $23 \mu \mathrm{l}$. PCR reactions were: denaturation $3 \mathrm{~min}$ at $95^{\circ} \mathrm{C}, 35 \mathrm{cycles}$ of $30 \mathrm{~s}$ at $95^{\circ} \mathrm{C}, 1$ $\min$ at $58^{\circ} \mathrm{C}$ and $1 \mathrm{~min}$ at $72^{\circ} \mathrm{C}$, and a final extension step of $7 \mathrm{~min}$ at $72^{\circ} \mathrm{C}$. PCR products were separated by agarose gel electrophoresis (1\%) and visualized with GelRed (Midore Green Advance DNA Stain). In order to assign a specific phylogroup or clade to the $10 \mathrm{E}$. coli strains isolated we used the PCR-based method described by Clermont et al., 2013 (Clermont, 2013). PCR products were separated by agarose gel electrophoresis (1\%) and visualized with GelRed (Midori Green Advance DNA Stain). The 10 E. coli isolates were further analyzed to obtain an unambiguous DNA fingerprint by Enterobacterial Repetitive Intergenic consensus (ERIC-PCR) as previously described (Versalovic, et al. 1991). ERIC-PCR products were separated by electrophoresis for $8 \mathrm{~h}$ at $40 \mathrm{~V} / \mathrm{cm}$, in 2\% agarose Tris borate-EDTA (TBE) gel stained with GelRed (Midori Green Advance DNA Stain). 
The strains ED1, ED4, ED8, ED157 and ED166 were chosen to be typed by Multi-Locus Sequence Typing (MLST) by sequence analysis of internal fragments of seven housekeeping genes (adk, fumC, gyrB, icd, mdh, purA, recA) according to the Achtman scheme (http://enterobase.warwick.ac.uk/species/index/ecoli). The allelic profiles of the seven genes and the resulting Sequence Type (ST) were determined from the submission of sequence data on the PubMLST database (https://pubmlst.org).

\subsubsection{Pathogenicity assay}

The hemolytic activity of the strains was evaluated as described by Ghosh et al. (2014) with some modifications. Briefly, $4 \mathrm{~mL}$ of freshly drawn, heparinized human blood was diluted with $25 \mathrm{~mL}$ of phosphate buffered saline (PBS), pH 7.4. After washing three times in $25 \mathrm{~mL}$ of PBS, the pellet was resuspended in PBS to $20 \mathrm{vol} \%$. A $100 \mu \mathrm{L}$ amount of erythrocyte suspension was added to $100 \mu \mathrm{L}$ of bacterial strains. PBS and $0.2 \%$ Triton X-100 were used as the negative and positive controls, respectively. After $1 \mathrm{~h}$ of incubation at $37{ }^{\circ} \mathrm{C}$ each well was centrifuged at $1200 \times \mathrm{g}$ for $15 \mathrm{~min}$, the supernatant was diluted 1:3 in PBS and transferred to a new plate. The OD350 was determined using the Synergy HT microplate reader spectrophotometer (BioTek, Winooski, VT, USA). The hemolysis (\%) was determined as follows:

$\left[\left(A-A_{0}\right) /\left(A_{\text {total }}-A_{0}\right)\right] \times 100$

where $A$ is the absorbance of the test well, $A_{0}$ the absorbance of the negative control, and $A_{\text {total }}$ the absorbance of the positive control; the mean value of three replicates was recorded.

To detect the biofilm development, the strains were grown in LB medium (Oxoid), adjusted to $5 \times 10^{6}$ $\mathrm{CFU} / \mathrm{mL}$ and inoculated $(100 \mu \mathrm{L})$ in 24-well polystyrene plates (VWR). After $24 \mathrm{~h}$ of incubation at $37^{\circ} \mathrm{C}$, and $24^{\circ} \mathrm{C}$ the wells were washed with PBS to eliminate unattached cells and covered with $0.1 \%(\mathrm{v} / \mathrm{v})$ crystal violet (CV) dissolved in $\mathrm{H}_{2} \mathrm{O}$ for 15 min, washed in PBS and air-dried. The remaining CV was dissolved in 85\% ethanol for $15 \mathrm{~min}$ at room temperature and $200 \mu \mathrm{L}$ from each well was transferred to a 24-well plate for spectrophotometric quantification at $570 \mathrm{~nm}$ (Multiscan Ex Microplate Reader, Thermo Scientific, Waltham, MA, USA. The strains were classified as strong, moderate, or weak biofilm producers based upon the ODs of the bacterial biofilms (Stepanović, et al. 2007). Quantification of biofilm in microtiter plates: overview of testing conditions and practical recommendations for assessment of biofilm production by staphylococci (Stepanović, et al. 2007). All assays were performed in triplicate using independent cultures.

\subsubsection{Genome sequencing and analysis}

Two strains, namely strains ED1 and ED157, were chosen for genome sequencing. These two strains were selected because they were both affiliated with the $D$ phylotype and because of their respective sequence type: ED1 belonged to a sequence type that contained many bacteria isolated from mammals including humans. The sequence type of ED157 only contained another E. coli strain that was isolated from water. The strains were grown in Luria Broth (LB, Merck Life Science) overnight and DNA extraction was performed using the ultraclean microbial DNA extraction kit (QIAGEN).

Purified DNA was sequenced on a NovaSeq Illumina Platform (IGA technologies, Padova, Italy), providing a total of 10 and 15 million reads of output for ED1 and ED157 strains, respectively. One of the two genomes was already mentioned in a previous article (Riva, et al. 2020). Briefly, reads were first trimmed using Trimmomatic (Bolger, et al. 2014) and genomes were assembled using SPAdes default parameters (Prjibelski, et al. 2020), obtaining a total of 54 and 59 assembled contigs $>1 \mathrm{~Kb}$, respectively.

To verify the phylotype of $E$. coli strains ED1 and ED157, we submitted the genome sequences to the website ClermoTyper (Beghain, et al. 2018). Plasmids' presence in the genomes was examined through the platform PlasmidFinder (Carattoli, et al. 2014), while the identification of antimicrobial resistance genes was done using ResFinder4.0 (Bortolaia, et al. 2020). Virulence genes were instead found using the 
VirulenceFinder 2.0 platform (Joensen, et al. 2014) and phage genome sequences were recognized using PHASTER (Arndt, et al. 2016).

In order to evaluate whether the Daphnia associated isolates were similar to other freshwater E. coli we compared them to other genomes from the D phylotype mentioned in Touchon et al. (2020): i) C4_38 and C2_45 strains, isolated from poultry meat, and ii) E5895 and E6003 strains, isolated from freshwater (Touchon et al., 2020; Tab. 1). Strains E5895 and E6003 were indeed randomly selected as representative E. coli strains adapted to the freshwater environment, owing a reduced genome, while the other two strains (C4_38 and C2_45) were randomly selected as representatives of strains from poultry meat, which are known to have the largest average genome within the E. coli species (Touchon et al., 2020).

Tab. 1. Escherichia coli genomes included in the study, their length, the isolation source, and the reference where they were first reported.

\begin{tabular}{lllll}
\hline Strain & Accession number & Total length (bp) & Isolation source & Reference \\
\hline ED1 & JAAWVB000000000 & 5159712 & Daphnia obtusa & Riva et al., 2020 \\
ED157 & JABEXY000000000 & 5273211 & Daphnia obtusa & This study \\
C4_38 & ERS3883848 & 5511727 & Poultry meat & Touchon et al., 2020 \\
C2_45 & ERS3883832 & 5623389 & Poultry meat & Touchon et al., 2020 \\
E5895 & ERS3883463 & 4825729 & Water & Touchon et al., 2020 \\
E6003 & ERS3883339 & 4771985 & Water & Touchon et al., 2020 \\
\hline
\end{tabular}

Phylogenetic analysis considering the whole genome sequences was performed through the MICROSCOPE platform (http://www.genoscope.cns.fr/agc/microscope (Blondel, et al. 2008; Vallenet, et al. 2009)). The phylogenetic tree was built with "genome clustering" MICROSCOPE tool. Genomic similarity was estimated using Mash, with distances correlated to ANI like: $D \approx 1$-ANI. From all the pairwise distances of the genomes set, a tree was constructed dynamically using the neighbor-joining javascript package, displaying clustering annotations. This clustering was computed from all-pairs distances $\leq 0.06(\approx 94 \% \mathrm{ANI})$, which correspond to the ANI standard to define a species group. Clustering was computed using the Louvain Community Detection.

In order to evidence differences and examine the distribution of protein families across the $E$. coli genomes indicated in Tab. 1, we used the "Protein Family Sorter" tool of PATRIC (https://www.patricbrc.org/), setting Genus-specific families (PLfams) (Davis, et al. 2016; Davis, et al. 2020).

\subsubsection{GFP and DsRed tagging of strains}

Competent cells of E. coli ED1 and ED157 strains were prepared in LB medium following the protocol described in Favia et al. (2007). Sixty microliters of competent cells $\left(\sim 10^{10}\right.$ cells $\left.\mathrm{ml}^{-1}\right)$ were mixed with 100$200 \mathrm{ng}$ of plasmid DNA, transferred to a cold $0.1-\mathrm{cm}$-diameter cuvette and pulsed at $1,700 \mathrm{~V}$ in the Electroporator 2510 apparatus (Eppendorf, Milan, Italy). Plasmids used were pHM2-Gfp (Favia, 2007) and pKan(DsRed) (Crotti, et al. 2009). Following the pulse, cells were immediately supplemented with $1 \mathrm{ml}$ of LB medium and incubated at $37^{\circ} \mathrm{C}$ for $1 \mathrm{~h}$. Transformants were selected by plating on LB agar medium added with i) $100 \mu \mathrm{g} \cdot \mathrm{ml}^{-1}$ kanamycin (KMY), $40 \mu \mathrm{g} \cdot \mathrm{ml}^{-1}$ 5-bromo-4-chloro-3-indolyl-b-D-galactopyranoside (X-Gal) and $0.5 \mathrm{mM}$ isopropyl-b-D-thiogalactopyranoside (IPTG) in case of plasmid pHM2-Gfp or ii) $100 \mu \mathrm{g} \cdot \mathrm{ml}^{-1} \mathrm{KMY}$ in case of plasmid pKan(DsRed). Verifications of the presence of pHM2-Gfp or pKan(DsRed) plasmids were done observing the bacterial cells by fluorescence microscopy. Furthermore, the identity of $E$. coli 
bioRxiv preprint doi: https://doi org/10.1101/2021.1223,474077; this version posted December 27, 2021. The copyright holder for this preprint (which was not certified by peer review) is the author/funder, who has granted bioRxiv a license to display the preprint in perpetuity. It is made available under aCC-BY-NC-ND 4.0 International license.

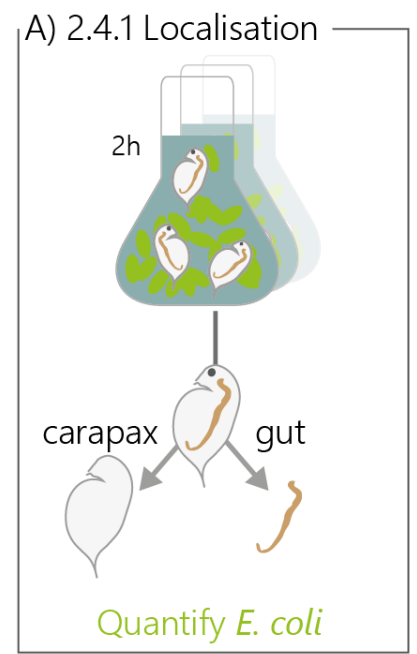

B) 2.4.2 Release of E. coli

transformants was confirmed by BOX-PCR amplification (Urzì, et al. 2001) by comparing the BOX-PCR profiles with those of wild type ED1 and ED157 strains.

C) 2.4.3 Persistence

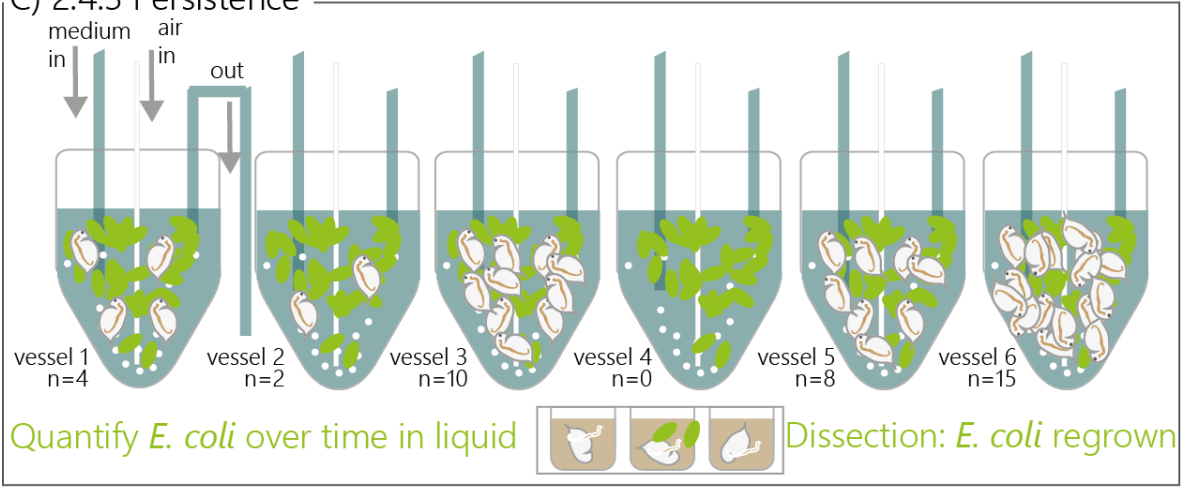

D) 2.4.4 Coexistence

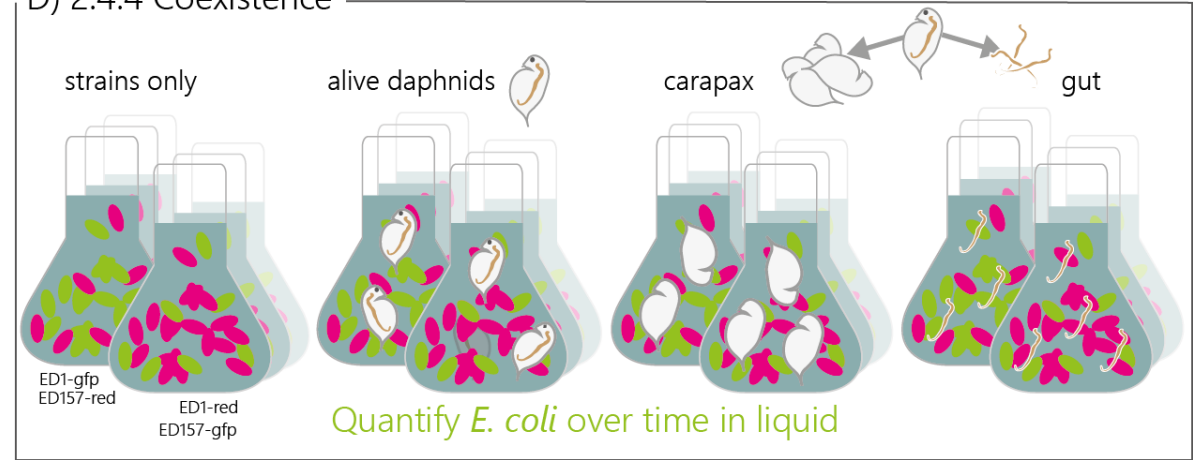

Figure 1 Experimental set-up of all experiments involving E. coli and Daphnia obtusa. A-D schematically depict the set-up of each experiment with the numbers corresponding to the subtitle within the material and method section 2.4. Experiments in $A, B$ and $D$ were conducted in batches, whereas experiment $C$ was conducted in a chemostat.

\subsection{Daphnia-E. coli association experiments}

All laboratory experiments were carried out using Daphnia obtusa from the garden of CNR-IRSA. The 
with artificial lake water medium (ALW, inorganic compounds in composition described here: (Zotina, et al. 2003)) and fed with a small amount of washed Kirchneriella sp. and kept in the dark before experimental use. The animals were washed again in ALW before each experiment and the experiments were conducted in the same medium if not specified differently. The E. coli strains ED1 and ED157 tagged with the fluorescent proteins which were used in the experiments were grown overnight at $37^{\circ} \mathrm{C}$ in liquid LB containing $100 \mu \mathrm{g} \cdot \mathrm{ml}^{-1} \mathrm{KMYto}$ maintain the plasmid. The strains were centrifuged and washed twice with ALW before inoculation in experimental treatments the next day. All experiments were carried out at room temperature in the dark. Figure 1 illustrates the approaches taken for the presented laboratory experiments. All figures of the experiments were drawn in $R$ (RCore Team 2013), using the packages ggplot2 (Wickham 2009), reshape2 (Wickham 2012) and cowplot (Wilke 2020).

\subsubsection{Localisation of E. coli on Daphnia}

We verified where E. coli attached to Daphnia by incubation of E. coli with live individuals Daphnia for 4 hours. Animals were then dissected and different body parts were subjected to qPCR amplification of the $g f p$-gene to verify the presence and quantify E. coli. qPCR assay was carried out in a volume of $20 \mu \mathrm{L}$ containing $2 \mu \mathrm{L}$ of DNA, $0.5 \mu \mathrm{M}$ of each primer (1-GAAGATGGAAGCGTTCAA and 2AGGTAATGGTTGTCTGGTA, (Hale, et al. 2015), $10 \mu \mathrm{L}$ of SsoAdvanced universal SYBR Green supermix (BioRad), and filtered and autoclaved MilliQ water (Millipore) to the final volume. The program of qPCR was $95^{\circ} \mathrm{C}$ for $2 \mathrm{~min}, 35 \mathrm{cycles}$ of $95^{\circ} \mathrm{C}$ for $15 \mathrm{~s}, 54^{\circ} \mathrm{C}$ for $30 \mathrm{~s}$ and $72{ }^{\circ} \mathrm{C}$ for $15 \mathrm{~s}$. Melting curve was performed from $60{ }^{\circ} \mathrm{C}$ to $95^{\circ} \mathrm{C}$ with increments of $0.5^{\circ} \mathrm{C} / 5 \mathrm{~s}$. The right size of all qPCR amplicons was evaluated by electrophoresis run (carried out as described above for uidA gene). The standard curve for the gfp-gene quantification was carried out by the dilution of the purified and quantified amplicon, as made for the uidA gene and previously described in Sabatino et al. (2015). The efficiency of reaction was $91 \%$ and R2 was 0.99. The LOQ (determined as described above for the uidA gene) was 9.85 gene copy/ $\mu \mathrm{L}$. The concentration of the $g f p$-gene was expressed as gene copy/daphnia.

\subsubsection{Release of $E$. coli after gut passage}

We then tested whether E. coli was a food source for Daphnia, if Daphnia functioned as a refuge for $E$. coli or if they simply passed through the gut. First we incubated ED1-gfp and ED157-gfp separately with and without Daphnia in $50 \mathrm{ml} \mathrm{ALW}$ for $2 \mathrm{~h}$ in the dark at room temperature, then we transferred $50 \mu \mathrm{l}$ of only water or water with a single Daphnia (+D treatment or control) and, after another $2 \mathrm{~h}$ of incubation, we compared the amount of ED1-gfp transferred in the surrounding water. ED1-gfp was counted on a flow cytometer as green fluorescent events (BD C6, Accuri). Differences between treatments were evaluated using a linear model on log-transformed count data for the response variable, conducted in $R$.

\subsubsection{Persistence of E. coli with Daphnia}

The chemostat was a continuous culturing system with three medium tanks containing ALW attached to six vessels containing $700 \mathrm{ml}$ of medium. A non-axenic Kirchneriella culture was added to both medium and vessels at a density of around 20,000 cells per $\mathrm{ml}(\mathrm{T}-5)$. The system was kept in the dark. After three days (T-2) the chemostat pumps were switched on with a daily water replacement rate of $10 \%$. After one day (T1) ED1-gfp was added to the vessel at a concentration of $10^{6}$ cells $\mathrm{l}^{-1}$ as well as algae to maintain around 20,000 cells $\mathrm{ml}^{-1}$. This experiment was conducted with strain ED1 because according to its sequence type it is a more relevant potential contamination from mammalian origin into freshwaters. After another day (TO) Daphnia obtusa was added to the vessels, which were randomly assigned with a quantity of animals in a gradient with the following number of animals per vessel: $0,2,6,8,10$ and 15 . Samples of $40 \mathrm{ml}$ were taken every 2-3 days over the outflow of the chemostat vessel and Kirchneriella solution was always added after sampling to maintain food for Daphnia. These samples were used for CFU counts for ED1-gfp and microscopy counts for both algae and ED1. For phytoplankton counts $10 \mathrm{ml}$ solution was filtered on 0.45 $\mu \mathrm{m}$ pore-size polycarbonate filters and at least 10 fields and 500 cells were counted at a magnification of $80^{\prime} 000 x$ at an epifluorescence microscope (Zeiss). For CFUs of day 0 and day 2 spots of $5 u$ of a gradual dilution between 1 and $10^{-4}$ were spotted on LB+KMY plates and grown for $24 \mathrm{~h}$ at $37^{\circ} \mathrm{C}$ and counted. The presence of the gfp and thus univocal identification of ED1-gfp was done by placing the plate on a 
transilluminator (UV light) and observation of green fluorescence of the colonies. Due to the strong reduction of $E$. coli numbers of CFU for T 5 and 7 were counted by filtration of $1 \mathrm{ml}$ of undiluted and 1:10 diluted sample and on $\mathrm{T} 9$ by filtration of $1 \mathrm{ml}$ and $10 \mathrm{ml}$ of sample, on a $0.2 \mu \mathrm{m}$ pore-size nitrocellulose membrane filter that was placed on the plates and colonies were counted as described above. All spots and filters were done in triplicate per sample. On T12 Daphnia numbers had strongly reduced (see Supplementary Table 1) thus the experiment was considered finished. Individuals of Daphnia were extracted from the vessels, washed 3 times with sterile ALW and then dissected; the different body parts were placed in 200ul LB+KMY in a black multiwell-plate in a plate reader (GlowMax, Promega). Growth of $E$. coli was detected by monitoring fluorescence over $48 \mathrm{~h}$ every $30 \mathrm{~min}$. The total number of adult dissected Daphnia was 12 ( 3 from vessel 6, 4 from vessel 5, 4 from vessel 3 and 1 from vessel 1 ) and the number of juvenile Daphnia was 9 ( 1 from vessel 6, 4 from vessel 5, 2 from vessel 3); 7 negative controls were included. We checked the influence of the original gradient of abundance of Daphnia on the CFU of E. coli by a generalised linear model assuming a negative binomial distribution of the data. The model was evaluated using check_model from the package performance (Lüdecke, et al. 2019) and the output depicted as a type II analysis of variance table using the car package (Fox, et al. 2012).

\subsubsection{Coexistence experiment}

In order to test whether ED1 and ED157 reacted similarly to the presence of Daphnia and its associated bacteria we conducted a batch experiment where we incubated both strains together with no Daphnia, alive Daphnia, and dissected Daphnia for which we made one treatment containing the Daphnia guts and one containing the Daphnia carapax and filtration apparatus and their associated bacteria. Each replicate was amended with either 3 alive Daphnia or dissection pieces from 10 Daphnia in $2 \mathrm{ml}$ in 1:100 diluted LB with ALW and in triplicate. Moreover each treatment was conducted twice once using ED1-gfp + ED157DsRed and once using ED1-DsRed and ED157-gfp to account for potential differences in fitness reduction by the two different fluorescence markers (total treatment $n=2$ stainings $\times 3$ replicates $\times 4$ treatments $=24$ ). In fact in both cases ED1-DsRed had a fitness advantage, thus the numbers presented here are averages between the CFUs counted for gfp and red of the same strain in the same treatment. CFUs were counted over 10 days starting from $\mathrm{T} 4$ on by spotting of 5 ul diluted up to $10^{-8}$ in triplicates and green and red colonies were counted on a trans-illuminator (UV). The experiment was stopped after 10 days due to major mortality of Daphnia in the alive treatment $(>90 \%)$ and data for the first 8 days was plotted. To evaluate the long-term differences between treatments data from March 24 and 26 were used (6 and 8 days). A generalised linear model assuming a negative binomial distribution of the data was made to evaluate the effect of the treatment and the date on the abundance of both E. coli ED1 and ED157 (g/m.nb in R with model: CFU treatment (4 levels: alive, carapax, gut, no Daphnia) + strain (2 levels: ED1 or ED157) + date (2 levels: March 24 and 26)). Model check and model output were performed as for the analysis of persistence of E. coli with Daphnia; in addition, pairwise differences between treatments were evaluated with a posthoc using emmeans from the homonymous package (Lenth 2020).

\subsection{Data and code accessibility}

All scripts and raw data are deposited at https://github.com/EsterME/E coli Daphnia. ED1 genome was deposited into the NCBI-Genbank database under accession number JAAWVB00000000 (Riva, et al. 2020). ED 157 Genome Shotgun project has been deposited at DDBJ/ENA/GenBank under the accession JABEXY000000000. The version described in this paper is version JABEXY010000000. 


\subsection{Abundance of $\mathrm{E}$. coli in Lake Maggiore}

By screening for the presence/abundance of the E. coli specific marker gene uidA in DNA extracted from three different locations in Lake Maggiore, we found that the gene was absent in the sediments, epilithic biofilms and water samples but could be found in both Daphnia gr. galeata/longispina and copepods, showing between 144-976 (mean 580) copies per animal (Figure 2A).

\subsection{E. coli in other zooplankton microbiomes}

We screened a large dataset of zooplankton-related microbiomes and could find the presence of $E$. coli/Shigella related 16S rRNA gene sequences in samples from other cladocerans (Daphnia magna, Daphnia obtusa, Diaphanosoma brachyurum) and rotifers (Adineta vaga, Keratella serrulata, Lecane elsa, Lecane inermis and Polyarthra sp.) (Figure 2B). E. coli/Shigella was not found in other rotifers (Epiphanes senta, Keratella quadrata), Mesocyclops leukarti, a large calanoid copepod, and the cladoceran Simocephalus sp. (Figure 2B). We quantified uidA in Daphnia obtusa sampled from a rainfed pond, because their E. coli/Shigella related reads were particularly high: we also confirmed the presence of $E$. coli uidA gene by qualitative Real Time PCR.

A)

B) $\begin{aligned} & \text { E. coli } \\ & \text { present? }\end{aligned}$

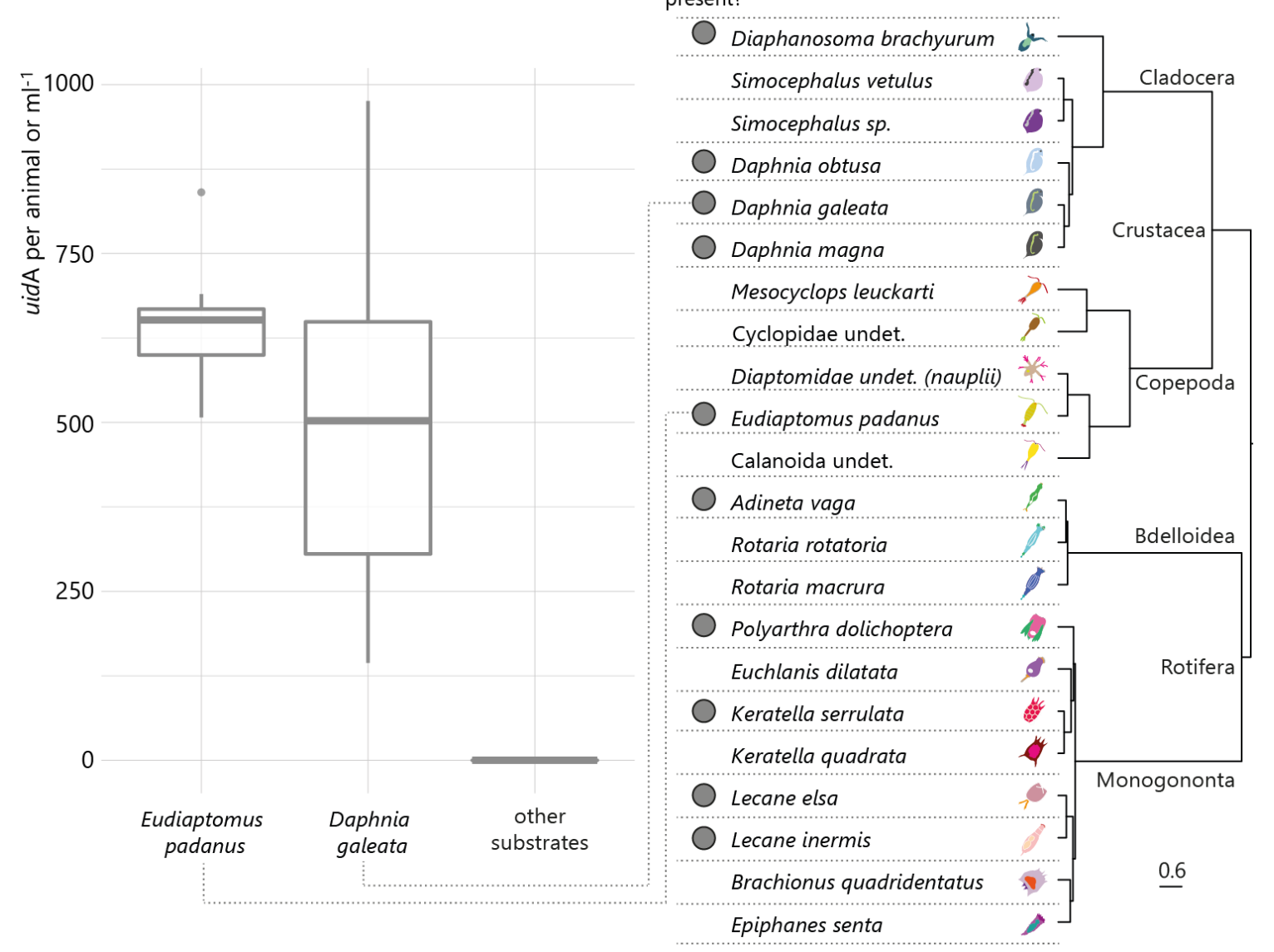

Figure 2 A) Boxplots of the abundance of the E. coli specific uidA gene copies in DNA isolated from animals and other substrates that include sediments, stones and water from 10 and $40 \mathrm{~m}$ depth from Lake Maggiore. For each plot, the tick horizontal line represents the median value, the box includes 50\% of the data from the first to the third quartile, the whiskers extend to the minimum and maximum data within the 1.5 interquartile range and the dots represent single outlier data points outside such range. B) Occurrence of $\mathrm{E}$. coli in various zooplankton species, a grey dot means E. coli was found in the microbiome of at least one sample. Images and phylogeny of animals are given as reference and are modified from Eckert et al, 2021. 


\subsection{E. coli isolates}

Isolation of E. coli from Daphnia obtusa

We attempted to isolate E. coli from Daphnia obtusa to further investigate which phylogroups of $E$. coli were affiliated with zooplankton. Through multiple isolation campaigns we retrieved ten $E$. coli strains and identified their phylogroup: strains ED1, ED2, ED3, ED4, and ED5 formed one cluster and were affiliated with phylogroup D/E and strains ED157, ED158 and ED166 a second cluster affiliated with phylogroup D/E (we did not succeed in the discrimination between these two phylogroups for these strains), strains ED8 and ED12 to phylogroup B1 (Figure 3A). Five of these strains were further chosen for MLST (ED1, ED4, ED8, ED157 and ED166) and pathogenicity assays: none of the strains showed traits of pathogenicity except for weak biofilm formation for the isolates ED1, ED4 and ED166 and they were classified in four different sequence types (ST38, ST1727, ST3573 and ST4166) (Figure 3A and Supplementary Table 2). We then analysed the strains deposited in the MLST database affiliated with these STs and most of the ST38 isolates were of human origin, whereas ST1727 included strains mostly isolated from animals (41\%) than from humans (10\%). The other two STs (ST3573 and ST4166) have been rarely described and they included isolates from non-human sources (Figure 3B).

ED1 and ED157 were selected for further analysis. The rationale behind the selection of these two isolates was their ST: ED1 was affiliated with ST38 where many other E. coli seem to be associated with mammals or even pathogens, whereas ED157 was affiliated with ST3573, including only one E. coli strain isolated from water. Genomes of ED1 and ED157 strains were sequenced and the strains were successfully marked with gfp and DsRed proteins, for interaction studies.

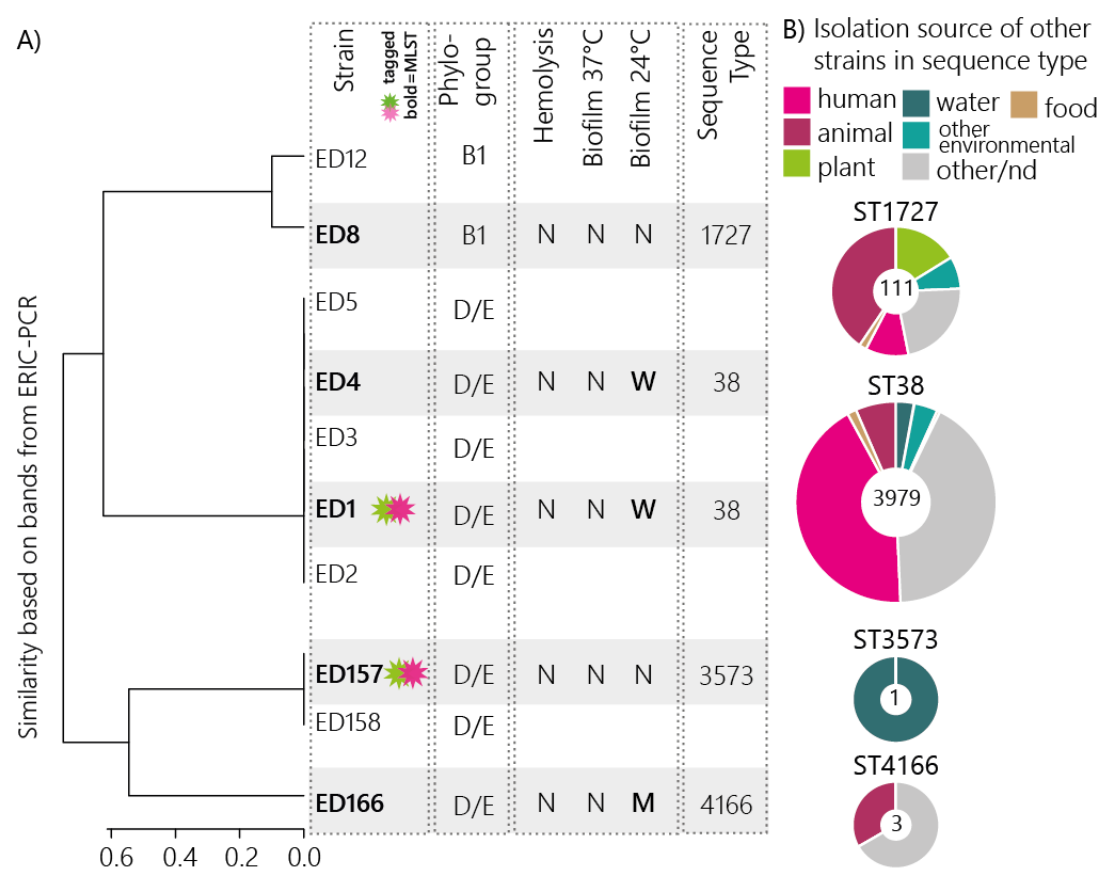

Figure 3 A. (fLTR) Cluster dendrogram of dissimilarity of the ERIC profile of the different E. coli strains isolated from D. obtusa and their phylogroup according to the ERIC profile. Strains that are grey shaded also present data for their phenotype in the pathogenicity assay ( $N=$ none, $M=$ medium and $W=$ weak), their sequence type according to Multi-locus sequence typing. B. Pie-charts summarising the isolation source of the deposited $\mathrm{E}$. coli strains of the same sequence type as the E. coli strains from daphnids; the number in the middle of the pie-charts denotes the number of strains deposited per each sequence type. 
Genome sequencing and analysis performed by ClermoTyper and phylogenetic tree construction with MICROSCOPE showed that ED1 and ED157 genomes belong to the D phylotype (Figure 4). Phylogenetic analysis performed on the whole genome sequences of the strains and genomes of water and poultry isolated $E$. coli showed that $E$. coli strains isolated from Daphnia sp. did not cluster with the water isolates. Conversely, strains isolated from poultry meat clustered with the genomes of the Daphnia isolates, whereas the water-related $E$. coli clustered in a sister group (Figure 4). Comparing genome size, we could observe that ED1 and ED157 genome size were bigger than the genome sequences of strains isolated from water, but smaller than the ones originated from poultry meat (Table 1). We found the presence of a higher number of plasmid replicon sequences in E. coli strains originated from poultry meat (C4_38: 5 plasmid replicon sequences; C2_45: 3 plasmid replicon sequences) than in the strains obtained from water (E5895: 1 plasmid replicon sequence; E6003: no plasmid replicon sequence detected) or from Daphnia obtusa (ED1: 2 plasmid replicon sequences; ED157: no plasmid replicon sequence detected) (Supplementary file 1). Poultry meat strains had a higher number of virulence genes (C4_38: 32; C2_45: 29) than the Daphnia strains (ED1: 12; ED157: 16) and the water strains (E5895: 10; E6003: 12) (Supplementary file 1). Our analysis revealed that more phage sequences were present in ED1 and ED157 genomes than in the other genomes analysed here. Specifically, we found 7 phage sequences in ED1 and 5 in ED157 (Supplementary file 1), whereas only three and 0.5 phage sequences were found in poultry and in water strains, respectively.

To compare which genes were different in the Daphnia isolates compared to other E. coli, a pangenomic analyses was done with the strains listed in table 1 using the protein family sorter tool of PATRIC (Supplementary Table 3). The pangenome was composed of 7108 protein families while the core genome consisted of 3789 protein families (53,7\%). E. coli isolated from poultry meat and from Daphnia shared $57.5 \%$ protein families (from a total of 6787 protein families), while E. coli isolated from Daphnia and from freshwater bodies shared 65\% (from a total of 5993 protein families).

The genomes from all groups shared a very high number of protein families that can help the strains to thrive in the different habitats: we found, for instance, the presence of protein families related to the production of the capsular polysaccharides, or the presence of protein families linked to the Type I fimbriae system. Interestingly, we detected the presence of RhS protein families, which are supposed to inhibit the intracellular growth as primary function (Koskiniemi, et al. 2013) and the presence of some protein families linked to sucrose utilization only in isolates from Daphnia and poultry meat. Focusing on the Accessory genome of $E$. coli isolated from Daphnia (i.e. protein families that were not found in the other two groups), specific groups included e.g. the presence of xanthosine-related protein families, which allow bacteria to utilize purine nucleoside as carbon and energy source, and the presence of poly-beta-1,6-N-acetyl-Dglucosamine (PGA) protein families, which are involved in the synthesis, the export and the localization of PGA polymer, a necessary component for the formation of biofilms, protecting the bacteria to adverse environmental conditions. 


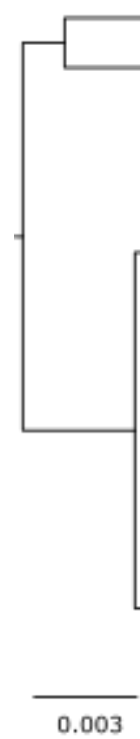

B2

Figure 4 Phylogenetic tree of E. coli genomes included in tab. 1. The tree was constructed with MICROSCOPE tool with a neighbour-joining algorithm on Mash genomic distances. The scale bar represents 0.003 substitutions per nucleotide position.

\subsection{Interaction of E. coli with Daphnia obtusa}

\section{Attachment}

First we verified where E. coli was localised in the animal by incubating ED1-gfp and ED157-gfp strains separately with live Daphnia for 4 hours, dissecting the animals and performing a qPCR assay targeting the $g f p$-gene to verify the presence of $E$. coli on the various body parts (Figure $1 \mathrm{~A}$ ). We found that $70 \pm 8 \%$ of the administered ED1-gfp and ED157-gfp were found in the gut compared to filter apparatus and carapax (data in Supplementary Table 4).

We then tested whether E. coli was digested by Daphnia or if Daphnia functioned as a refuge for $E$. coli or if they simply passed through the gut. We incubated ED1-gfp and ED157-gfp with Daphnia for 4 hours and then transferred them to new clean water (Figure 1B). Compared to the control (transferred water without Daphnia) we found a significantly higher abundance of both $E$. coli strains in the surrounding water of Daphnia (Figure 5). 


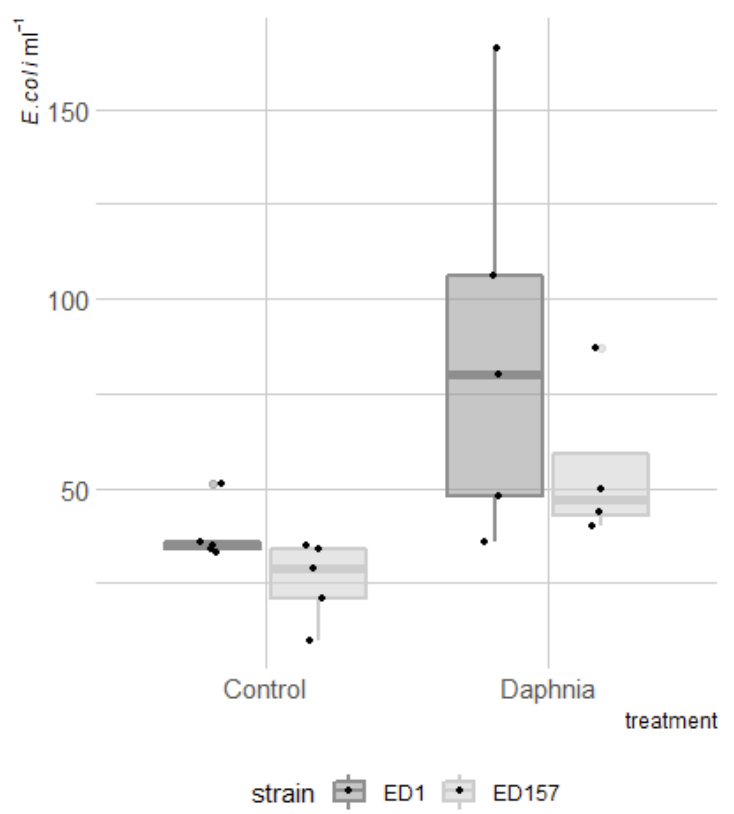

Figure $5 \mathrm{E}$. coli density in the treatment where only water was transferred (Control) and where animals were transferred (Daphnia) to sterile water after feeding on E. coli strains ED1-gfp (dark grey) or ED157-gfp (light grey). For each plot, the tick horizontal line represents the median value, the box includes $50 \%$ of the data from the first to the third quartile, the whiskers extend to the minimum and maximum data within the 1.5 interquartile range and the grey dots represent single outlier data points outside such range. The original data points for each treatment are superimposed on the plots as jittered black dots.

\section{Persistence with and without Daphnia}

We investigated how the presence of Daphnia impacted on the general survival of ED1-gfp in freshwater systems in continuous culture experiments (chemostat). We therefore filled eight chemostat vessels with ALW, a phytoplankton culture, E. coli and incubated Daphnia at different densities $(0,2,4,8,10,15$ animals per vessel, Figure $1 C$ ). We monitored the abundance of culturable $E$. coli overtime in the water and found that the number of Daphnia had a slightly significant negative effect on the abundance of $E$. coli $(\mathrm{glm}$ : Estimate $=-0.11 \pm 0.06, z=-2, p=0.048$ ). However, culturable $E$. coli abundances were in the same order of magnitude with only 1-6 CFU detected per ml of surrounding water in all treatments after 10 days of incubation even without animals (Figure 6). Some animals were then washed and guts dissected and E. coli cells were regrown in a plate reader to see whether there were culturable E. coli cells in the gut of the animals. One fourth of the total 12 dissected adult Daphnia ( 2 from vessel 5 and 1 from vessel 3,0 from vessel 6 and 1 ) resulted in growth of E. coli within the first $48 \mathrm{~h}$ of incubation, whereas no growth was detected from the gut of juvenile animals (total of 9 animals, Supplementary data 2). 
463

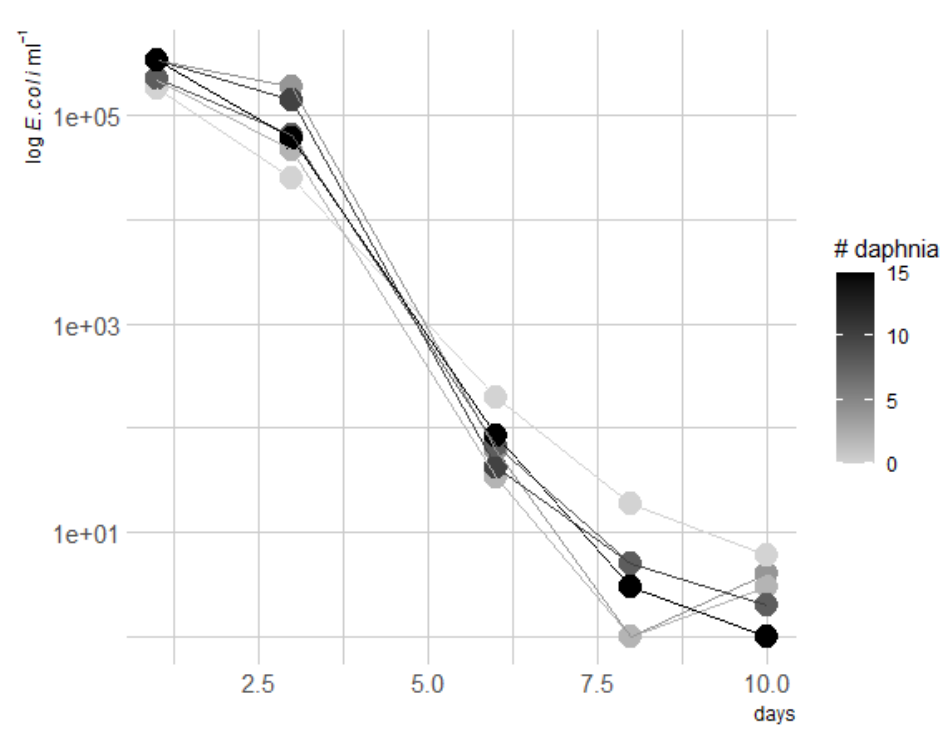

Figure 6 Log transformed cell density of tagged $\mathrm{E}$. coli in chemostat experiment over time. The shade of grey of the dots and lines indicates the starting number of Daphnia obtusa added to the vessels.

\section{Coexistence of ED1 and ED157}

We then conducted an additional experiment where we combined both strains ED1-gfp with ED157-DsRed and ED157-gfp with ED157-DsRed, respectively, and incubated them either without animals, alive animals, dissected guts or dissected carapax (Figure 1D). At day 6 and 8 the abundances of culturable ED1 and ED157 (average of both tag combinations) were not statistically different (Figure 7, Table 2) whereas differences in treatments were visible: all treatments were different from each other except for the treatment with no Daphnia and the treatment with carapax pieces (Table 2). Living animals caused a faster reduction of $E$. coli abundances in the surrounding water than the other treatments. E. coli growth with carapax pieces increased in numbers notwithstanding the presence of other bacteria and reached numbers that were very similar to the treatment that contained only the tagged-strains. In the presence of gut pieces and naturally associated gut bacteria the abundances of both strains were reduced much more rapidly and at the end their abundance was similar to the one with live Daphnia (Figure 7).

Tab. 2. A. Statistical output from the generalised linear model made for the coexistence experiment to evaluate the dependence of the abundance of $\mathrm{E}$. coli on the treatment (four levels: alive, carapax, gut, and strains only), the strain (two levels: ED1 and ED157) and the sampling date (two levels: May $24^{\text {th }}$ and $26^{\text {th }}$ ). The table is a type-Il analysis-of-variance table with Wald chi-square tests for predictors. B. Significance of the differences in the pairwise comparisons between the four treatments from a Tukey post hoc test. *** means $p$ value $<0.001, * p$ value $<0.05$ and n.s. $p$ value $>0.05$

\begin{tabular}{lllll}
\hline A. & $\begin{array}{l}\text { Chi- } \\
\text { square } \\
\text { value }\end{array}$ & $\begin{array}{l}\text { degrees } \\
\text { of } \\
\text { freedom }\end{array}$ & p value & \\
\hline treatment & 52.2 & 3 & $<0.0001$ & $* * *$ \\
strain & 1.2 & 1 & 0.2830 & \\
date & 4.8 & 1 & 0.0284 & $*$ \\
\hline B. & Carapax & Gut & Strains \\
\hline
\end{tabular}




\begin{tabular}{|c|c|c|c|}
\hline & & & only \\
\hline Alive & $* * *$ & $* * *$ & $* * *$ \\
\hline Carapax & & $*$ & n.s. \\
\hline Gut & & & $* * *$ \\
\hline
\end{tabular}
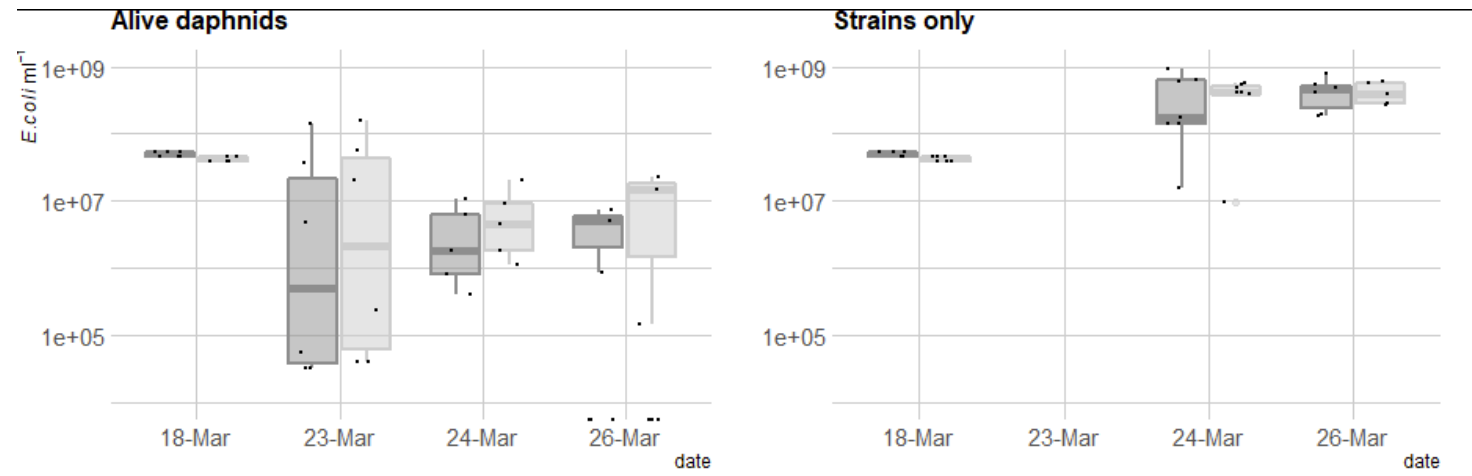

Carapax

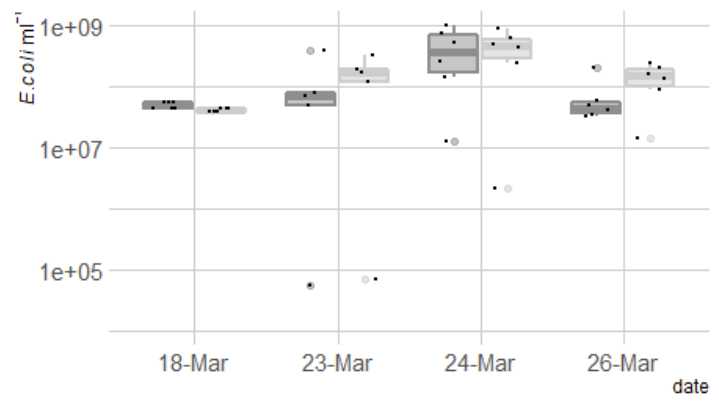

Gut

strain $\doteqdot$ ED1 $\risingdotseq$ ED157

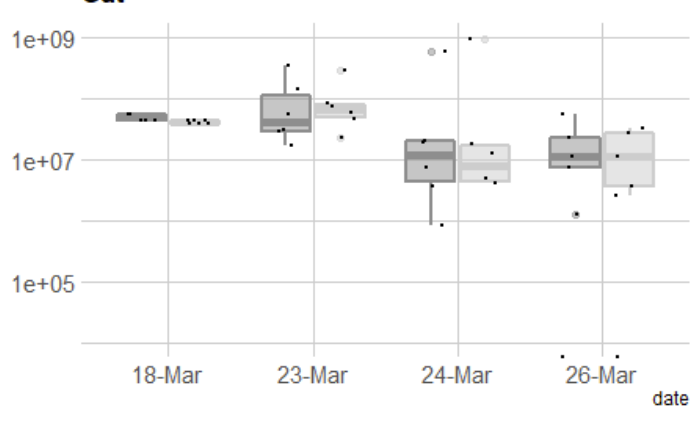

strain $\risingdotseq \mathrm{ED} 1 \div \mathrm{ED} 157$

Figure $7 \mathrm{E}$. coli cell density over time in a batch experiment with the addition of Daphnia obtusa (Alive daphnids), no daphnids (strains only), pieces of Daphnia carapax (Carapax) and gut pieces (gut). Dark grey shows ED1 and light grey ED157 strains labelled with fluorescent proteins. 


\section{Discussion}

In this study we tackled the question whether Daphnia was a host for $E$. coli in freshwaters. While on one hand these bacteria are known to not be competitive in such environments and to be grazed easily when entering freshwaters through faecal pollution (i.e. (González, et al. 1992; Eckert, et al. 2019)), the evolution of freshwater E. coli (Touchon, et al. 2020) and renaturation of these bacteria have been observed (Ishii, Ksoll, et al. 2006; Ishii and Sadowsky 2008), showing that at least part of the incoming E. coli must survive over longer time periods in water. In a previous study we found that lake zooplankton could show remarkable quantities of $E$. coli related 16S rRNA gene sequences and we confirmed this here by quantifying the abundance of uidA gene, an unambiguous indicator for E. coli presence (Figure 2) (Eckert, et al. 2020). Indeed, this is not the first time that $E$. coli is found associated with zooplankton (Ishii, Yan, et al. 2006). Evidence is accumulating that freshwater zooplankton microbiota is rather flexible in terms of composition (Callens, et al. 2015; Macke, et al. 2020; Eckert, et al. 2021; Pfenning-Butterworth, et al. 2021), meaning that the association with zooplankton might be an interesting potential niche for the short-term survival of FIB. Such a habitat offers protection from protistan grazing and higher nutrient concentrations thanks to filtration feeding from the animal (Eckert and Pernthaler 2014). Furthermore, surface attachment is generally considered favourable for the survival of such bacteria compared to a planktonic lifestyle (Costerton, et al. 1999; Allen, et al. 2010). We thus tested here whether the association with Daphnia allowed $E$. coli to survive longer in aquatic habitats compared to when the animal was not present. In this study we found that Daphnia can function as a short-term and transitional host for E. coli: as hypothesised, Daphnia did reduce abundances of $E$. coli in the surrounding waters but it was not responsible for the complete removal of $E$. coli, since many bacterial cells survived gut passages (Figure 5 ) and $E$. coli was still detected after 10 days of co-culturing with Daphnia (Figures 5 and 6). In this study we confirm that $E$. coli localizes mainly in the gut of Daphnia and that at least part of its population survives the gut passage (Burnet, et al. 2017; Ismail, et al. 2019). However, the association with Daphnia obtusa did not seem to give a long term advantage in the survival of $E$. coli (Figures 6\&7).

Many studies have recently suggested to use Daphnia as a biological controlling mechanism for $E$. coli contaminations in water: through experiments using very large densities of animals and bacteria these studies showed that the abundance of E. coli was reduced due to grazing of Daphnia (Nørgaard and Roslev 2016; Burnet, et al. 2017; Ismail, et al. 2019). The addition of Daphnia is surely feasible to reduce large abundances of E. coli, but here we showed that E. coli persisted even in the presence of Daphnia in low abundances that were more similar to those found in nature. In fact, we also showed that $E$. coli was still culturable from the gut, even if the bacterium was in very low abundance in the surrounding water. In our environmental survey we found it associated with different zooplankton hosts, especially cladocerans and rotifers (Figure 2), but particularly abundant in a specific sample of zooplankton from Lake Maggiore (Figure 2). However, also other samples from Lake Maggiore were analysed in the large study of zooplanktonassociated microbes (Eckert, et al. 2021), and we did not find any E. coli in these. This shows that the shortterm association can also occur in nature and that such association might consequently also spread $E$. coli that enter the system through superficial contamination due to the animals vertical and horizontal migration (Grossart, et al. 2010). However, there does not seem to be an actual persistence of these bacteria, indicating that the occurrences in the gut are rather stochastic events and that $E$. coli does not form part of the general Daphnia microbiota.

In the experiment where we incubated $E$. coli with dissected guts we observed a similar reduction of the bacteria (after 8 days) as was seen with alive Daphnia (Figure 7). This data strongly indicates that the competition with the gut microbiota was the main reason for reduced abundances of $E$. coli. Another interesting finding was that $E$. coli seemed to profit from the presence of carapax pieces of Daphnia, which are composed mostly of chitin. Both strains grew better in the presence of carapax, despite they did not have chitinolytic enzymes in their genome. It is more likely that the two strains indirectly profited from chitin degradation since such degradation is usually more efficient when done by multiple species (Corno, et al. 2015) and many bacteria are known to profit from these compounds without being directly involved in the primary degradation (Beier and Bertilsson 2013). The presence of poly-beta-1,6-N-acetyl-D- 
glucosamine (PGA) protein families, which are involved in the synthesis, the export and the localization of PGA polymer, shows that these $E$. coli strains might also be involved in multispecies biofilm formation (Kang, et al. 2018).

We isolated E. coli from Daphnia collected from a small pond, however with major difficulty. Despite multiple isolation campaigns and a clear presence of $E$. coli, confirmed by amplification of the uidA gene in these pond daphnids, we only isolated ten strains (Figure 3). This could mean that E. coli associated with Daphnia were in a viable but nonculturable state (VBNC), which has been observed in other freshwater environments (Liu, et al. 2008) or when exposed to sunlight (Pommepuy, et al. 1996). For Enterococcus faecalis it was shown that much higher numbers are detected attached to plankton with cultureindependent methods, compared to the culturable fraction of these bacteria, and it has been suggested that this attachment in a VBNC state is a mode of survival of this species in freshwater (Signoretto, et al. 2004). A similar situation might also be true for E. coli.

The E. coli strains isolated from Daphnia in this study belonged to phylogroups D/E or B1. The analysis of our Daphnia deriving E. coli strains themselves did not give strong indication that these were environmental strains. Touchon and colleagues have shown that freshwater $E$. coli strains had a reduced genome (Touchon, et al. 2020), a typical form of adaptation to oligotrophic environments (Baumgartner, et al. 2017; Salcher, et al. 2019). In an experimental system Baumgartner and colleagues showed that such genome reduction was rather fast when bacteria were under predation (only a few hundred generations, Baumgartner, et al. 2017 (Baumgartner, et al. 2016)). In the case of our E. coli strains their genome was of intermediate size, meaning that they were smaller than the genomes found in poultry meat derived E. coli, but larger than those of freshwater E. coli, which could indicate a certain transition to adaptation of the genome. The two analysed Daphnia-associated E. coli genomes did not cluster with the freshwater isolates but with those isolated from poultry meat. In fact also the $E$. coli strains isolated from freshwater might derive from avian faeces (Meerburg, et al. 2011) and survive associated with zooplankton for a short time. The E. coli genomes also showed some traits that were considered important to adapt to different environments and for survival in freshwater, e.g., the presence of protein families related to the production of the capsular polysaccharides, which protect the bacteria from several environmental stress factors (Walk, et al. 2007; Azurmendi, et al. 2020), or the presence of protein families linked to the Type I fimbriae system, which allows bacteria to attach to several eukaryotic cells (Gally, et al. 1993). Whether or not zooplankton is a place of genetic adaptation of FIB to the environment is an interesting question arising from this study.

Overall our results showed that the FIB E. coli, when released into the aquatic environment, can form a short-term association with zooplankton, e.g. Daphnia. We demonstrated that $E$. coli does not belong to the core microbiota of Daphnia, suffers from competition by the natural microbiota of Daphnia, but may resist passages through its gut and profit of its carapax to survive in water. This association did not prolong their long-term survival in our experiments, but might provide a niche where these bacteria can encounter other aquatic bacteria, a possible spot for horizontal gene transfer, and a possible spot for genomic adaptation. 
bioRxiv preprint doi: https://doi org/10.1101/2021.12.23,474077; this version posted December 27, 2021. The copyright holder for this preprint (which was not certified by peer review) is the author/funder, who has granted bioRxiv a license to display the preprint in perpetuity. It is made available under aCC-BY-NC-ND 4.0 International license.

Acknowledgments

PJC-Y was supported by a APOSTD/2019/009 Post-Doctoral Fellowship from Generalitat Valenciana. Waters (CIPAIS).

599 Author contribution:

EME, ADC, DF and GC designed the study. ADC and NC isolated E. coli, VM and CC characterised E. coli phenotypes, CV, GM, NC and BC characterised E. coli by MLST, PJCY, FR and EC analysed E. coli genomes, $\mathrm{SB}, \mathrm{EC}$ and $\mathrm{FM}$ marked E. coli strains, EME and DF analysed $16 \mathrm{~S}$ amplicon sequencing data, EME, DF, ADC, $G B, W Q$ and $G C$ conducted laboratory experiments, $A D C$ and $E E$ wrote the article with contribution from all the authors. 


\section{References}

Abgottspon H, Nüesch-Inderbinen MT, Zurfluh K, Althaus D, Hächler H, Stephan R. 2014.

Enterobacteriaceae with extended-spectrum- and pAmpC-type ß-lactamase-encoding genes isolated from freshwater fish from two lakes in Switzerland. Antimicrobial Agents and Chemotherapy 58:2482-2484. Allen HK, Donato J, Wang HH, Cloud-Hansen KA, Davies J, Handelsman J. 2010. Call of the wild: antibiotic resistance genes in natural environments. Nature Reviews Microbiology 8:251-259.

Arndt D, Grant JR, Marcu A, Sajed T, Pon A, Liang Y, Wishart DS. 2016. PHASTER: a better, faster version of the PHAST phage search tool. Nucleic Acids Research 44:W16-W21.

Azurmendi HF, Veeramachineni V, Freese S, Lichaa F, Freedberg DI, Vann WF. 2020. Chemical structure and genetic organization of the E. coli O6: K15 capsular polysaccharide. Scientific Reports 10:1-12.

Baniga Z, Hounmanou YMG, Kudirkiene E, Kusiluka LM, Mdegela RH, Dalsgaard A. 2020. Genome-Based Analysis of Extended-Spectrum $\beta$-Lactamase-Producing Escherichia coli in the Aquatic Environment and Nile Perch (Lates niloticus) of Lake Victoria, Tanzania. Frontiers in microbiology 11.

Baumgartner M, Neu TR, Blom JF, Pernthaler J. 2016. Protistan predation interferes with bacterial longterm adaptation to substrate restriction by selecting for defence morphotypes. Journal of Evolutionary Biology:n/a-n/a.

Baumgartner M, Roffler S, Wicker T, Pernthaler J. 2017. Letting go: bacterial genome reduction solves the dilemma of adapting to predation mortality in a substrate-restricted environment. The ISME journal 11:2258-2266.

Beghain J, Bridier-Nahmias A, Le Nagard H, Denamur E, Clermont O. 2018. ClermonTyping: an easy-to-use and accurate in silico method for Escherichia genus strain phylotyping. Microbial Genomics 4. Beier S, Bertilsson S. 2013. Bacterial chitin degradation-mechanisms and ecophysiological strategies. Frontiers in microbiology 4.

Blondel VD, Guillaume J-L, Lambiotte R, Lefebvre E. 2008. Fast unfolding of communities in large networks. Journal of Statistical Mechanics: Theory and Experiment 2008:P10008.

Bolger AM, Lohse M, Usadel B. 2014. Trimmomatic: a flexible trimmer for Illumina sequence data. Bioinformatics 30:2114-2120.

Bortolaia V, Kaas RS, Ruppe E, Roberts MC, Schwarz S, Cattoir V, Philippon A, Allesoe RL, Rebelo AR, Florensa AF. 2020. ResFinder 4.0 for predictions of phenotypes from genotypes. Journal of Antimicrobial Chemotherapy 75:3491-3500.

Burnet JB, Faraj T, Cauchie HM, Joaquim-Justo C, Servais P, Prévost M, Dorner SM. 2017. How does the cladoceran Daphnia pulex affect the fate of Escherichia coli in water? Plos One 12:e0171705.

Bustin SA, Benes V, Garson JA, Hellemans J, Huggett J, Kubista M, Mueller R, Nolan T, Pfaffl MW, Shipley GL. 2009. The MIQE guidelines: minimum information for publication of quantitative real-time PCR experiments. Clinical chemistry 55:611-622.

Callens M, De Meester L, Muylaert K, Mukherjee S, Decaestecker E. 2020. The bacterioplankton community composition and a host genotype dependent occurrence of taxa shape the Daphnia magna gut bacterial community. FEMS Microbiology Ecology 96:fiaa128.

Callens M, Macke E, Muylaert K, Bossier P, Lievens B, Waud M, Decaestecker E. 2015. Food availability affects the strength of mutualistic host-microbiota interactions in Daphnia magna. The ISME journal. Carattoli A, Zankari E, García-Fernández A, Voldby Larsen M, Lund O, Villa L, Møller Aarestrup F, Hasman H. 2014. In Silico Detection and Typing of Plasmids using PlasmidFinder and Plasmid Multilocus Sequence Typing. Antimicrobial Agents and Chemotherapy 58:3895-3903.

Corno G, Salka I, PohImann K, Hall AR, Grossart H-P. 2015. Interspecific interactions drive chitin and cellulose degradation by aquatic microorganisms. Aquatic Microbial Ecology 76:27-37.

Costerton JW, Stewart PS, Greenberg EP. 1999. Bacterial biofilms: a common cause of persistent infections. Science 284:1318-1322.

Crotti E, Damiani C, Pajoro M, Gonella E, Rizzi A, Ricci I, Negri I, Scuppa P, Rossi P, Ballarini P. 2009. Asaia, a versatile acetic acid bacterial symbiont, capable of cross-colonizing insects of phylogenetically distant genera and orders. Environmental microbiology 11:3252-3264.

Davis JJ, Gerdes S, Olsen GJ, Olson R, Pusch GD, Shukla M, Vonstein V, Wattam AR, Yoo H. 2016. PATtyFams: Protein Families for the Microbial Genomes in the PATRIC Database. Front Microbiol 7:118. 
bioRxiv preprint doi: https://doi.org/10.1101/2021.12.23.474077; this version posted December 27, 2021. The copyright holder for this preprint (which was not certified by peer review) is the author/funder, who has granted bioRxiv a license to display the preprint in perpetuity. It is made available under aCC-BY-NC-ND 4.0 International license.

Davis JJ, Wattam AR, Aziz RK, Brettin T, Butler R, Butler RM, Chlenski P, Conrad N, Dickerman A, Dietrich EM, et al. 2020. The PATRIC Bioinformatics Resource Center: expanding data and analysis capabilities. Nucleic Acids Research 48:D606-D612.

Declerck P, Behets J, van Hoef V, Ollevier F. 2007. Detection of Legionella spp. and some of their amoeba hosts in floating biofilms from anthropogenic and natural aquatic environments. Water research 41:31593167.

Eckert EM, Amalfitano S, Di Cesare A, Manzari C, Corno G, Fontaneto D. 2020. Different substrates within a lake harbour connected but specialised microbial communities. Hydrobiologia 847:1689-1704.

Eckert EM, Anicic N, Fontaneto D. 2021. Freshwater zooplankton microbiome composition is highly flexible and strongly influenced by the environment. Molecular ecology 30:1545-1558.

Eckert EM, Di Cesare A, Coci M, Corno G. 2018. Persistence of antibiotic resistance genes in large subalpine lakes: the role of anthropogenic pollution and ecological interactions. Hydrobiologia 824:93-108.

Eckert EM, Di Cesare A, Stenzel B, Fontaneto D, Corno G. 2016. Daphnia as a refuge for an antibiotic resistance gene in an experimental freshwater community. Science of The Total Environment 571:77-81. Eckert EM, Pernthaler J. 2014. Bacterial epibionts of Daphnia: a potential route for the transfer of dissolved organic carbon in freshwater food webs. ISME J 8:1808-1819.

Eckert EM, Quero GM, Di Cesare A, Manfredini G, Mapelli F, Borin S, Fontaneto D, Luna GM, Corno G. 2019. Antibiotic disturbance affects aquatic microbial community composition and food web interactions but not community resilience. Molecular ecology 28:1170-1182.

Espinosa-Urgel M, Kolter R. 1998. Escherichia coli genes expressed preferentially in an aquatic environment. Mol Microbiol 28:325-332.

Favia G, Ricci I, Damiani C, Raddadi N, Crotti E, Marzorati M, Rizzi A, Urso R, Brusetti L, Borin S, et al. 2007. Bacteria of the genus \&lt;em\&gt;Asaia\&lt;/em\&gt; stably associate with \&lt;em\&gt;Anopheles stephensi\&lt;/em\&gt;, an Asian malarial mosquito vector. Proceedings of the National Academy of Sciences 104:9047.

Fernandes MR, Sellera FP, Moura Q, Esposito F, Sabino CP, Lincopan N. 2020. Identification and genomic features of halotolerant extended-spectrum- $\beta$-lactamase (CTX-M)-producing Escherichia coli in urbanimpacted coastal waters, Southeast Brazil. Marine pollution bulletin 150:110689.

Fox J, Weisberg S, Adler D, Bates D, Baud-Bovy G, Ellison S, Firth D, Friendly M, Gorjanc G, Graves S. 2012. Package 'car'. Vienna: R Foundation for Statistical Computing.

Gally DL, Bogan JA, Eisenstein BI, Blomfield IC. 1993. Environmental regulation of the fim switch controlling type 1 fimbrial phase variation in Escherichia coli K-12: effects of temperature and media. Journal of Bacteriology 175:6186-6193.

Ghosh C, Manjunath GB, Akkapeddi P, Yarlagadda V, Hoque J, Uppu DSSM, Konai MM, Haldar J. 2014. Small Molecular Antibacterial Peptoid Mimics: The Simpler the Better! Journal of Medicinal Chemistry 57:14281436.

González JM, Iriberri J, Egea L, Barcina I. 1992. Characterization of culturability, protistan grazing, and death of enteric bacteria in aquatic ecosystems. Applied and environmental microbiology 58:998-1004.

Grossart HP, Dziallas C, Leunert F, Tang KW. 2010. Bacteria dispersal by hitchhiking on zooplankton.

Proceedings of the National Academy of Sciences of the United States of America 107:11959-11964.

Grote J, Thrash JC, Huggett MJ, Landry ZC, Carini P, Giovannoni SJ, Rappé MS. 2012. Streamlining and core genome conservation among highly divergent members of the SAR11 clade. mBio 3.

Hale L, Luth M, Crowley D. 2015. Biochar characteristics relate to its utility as an alternative soil inoculum carrier to peat and vermiculite. Soil Biology and Biochemistry 81:228-235.

Hall-Stoodley L, Stoodley P. 2005. Biofilm formation and dispersal and the transmission of human pathogens. Trends in Microbiology 13:7-10.

Haller L, Poté J, Loizeau J-L, Wildi W. 2009. Distribution and survival of faecal indicator bacteria in the sediments of the Bay of Vidy, Lake Geneva, Switzerland. Ecological Indicators 9:540-547. Hammer TJ, Sanders JG, Fierer N. 2019. Not all animals need a microbiome. FEMS Microbiology Letters 366:fnz117.

Ishii S, Ksoll WB, Hicks RE, Sadowsky MJ. 2006. Presence and growth of naturalized Escherichia coli in temperate soils from Lake Superior watersheds. Applied and environmental microbiology 72:612-621. 
Ishii S, Sadowsky MJ. 2008. Escherichia coli in the environment: implications for water quality and human health. Microbes and environments 23:101-108.

Ishii S, Yan T, Shively DA, Byappanahalli MN, Whitman RL, Sadowsky MJ. 2006. Cladophora (Chlorophyta) spp. harbor human bacterial pathogens in nearshore water of Lake Michigan. Applied and environmental microbiology 72:4545-4553.

Ismail NS, Blokker BM, Feeney TR, Kohn RH, Liu J, Nelson VE, Ollive MC, Price SBL, Underdah EJ. 2019. Impact of Metazooplankton Filter Feeding on Escherichia coli under Variable Environmental Conditions. Appl Environ Microbiol 85.

Jang J, Hur HG, Sadowsky MJ, Byappanahalli M, Yan T, Ishii S. 2017. Environmental Escherichia coli: ecology and public health implications-a review. Journal of Applied Microbiology 123:570-581.

Joensen KG, Scheutz F, Lund O, Hasman H, Kaas RS, Nielsen EM, Aarestrup FM. 2014. Real-time wholegenome sequencing for routine typing, surveillance, and outbreak detection of verotoxigenic Escherichia coli. Journal of clinical microbiology 52:1501-1510.

John P, Haller L, Kottelat R, Sastre V, Arpagaus P, Wildi W. 2009. Persistence and growth of faecal culturable bacterial indicators in water column and sediments of Vidy Bay, Lake Geneva, Switzerland. Journal of Environmental Sciences 21:62-69.

Jørgensen SB, Søraas AV, Arnesen LS, Leegaard TM, Sundsfjord A, Jenum PA. 2017. A comparison of extended spectrum $\beta$-lactamase producing Escherichia coli from clinical, recreational water and wastewater samples associated in time and location. Plos One 12:e0186576.

Kang J, Li Q, Liu L, Jin W, Wang J, Sun Y. 2018. The specific effect of gallic acid on Escherichia coli biofilm formation by regulating pgaABCD genes expression. Applied Microbiology and Biotechnology 102:18371846.

Korajkic A, Wanjugi P, Brooks L, Cao Y, Harwood Valerie J. 2019. Persistence and Decay of Fecal Microbiota in Aquatic Habitats. Microbiology and molecular biology reviews 83:e00005-00019.

Koskiniemi S, Lamoureux JG, Nikolakakis KC, Kint de Roodenbeke C, Kaplan MD, Low DA, Hayes CS. 2013. Rhs proteins from diverse bacteria mediate intercellular competition. Proceedings of the National Academy of Sciences 110:7032.

Lee M-C, Marx CJ. 2012. Repeated, selection-driven genome reduction of accessory genes in experimental populations. PLoS Genet 8:e1002651.

Lenth RV. 2020. emmeans: Estimated Marginal Means, aka Least-Squares Means., Liu Y, Gilchrist A, Zhang J, Li X-F. 2008. Detection of Viable but Nonculturable <i>Escherichia coli</i> 0157:H7 Bacteria in Drinking Water and River Water. Applied and environmental microbiology 74:15021507.

Lüdecke D, Makowski D, Waggoner P. 2019. Performance: assessment of regression models performance. $R$ package version 0.42 .

Macke E, Callens M, Massol F, Vanoverberghe I, De Meester L, Decaestecker E. 2020. Diet and Genotype of an Aquatic Invertebrate Affect the Composition of Free-Living Microbial Communities. Frontiers in microbiology 11:380.

Martinson JN, Walk ST. 2020. Escherichia coli residency in the gut of healthy human adults. EcoSal Plus 9. Meerburg BG, Koene MGJ, Kleijn D. 2011. Escherichia coli Concentrations in Feces of Geese, Coots, and Gulls Residing on Recreational Water in The Netherlands. Vector-Borne and Zoonotic Diseases 11:601-603. Nørgaard LS, Roslev P. 2016. Effects of ammonia and density on filtering of commensal and pathogenic Escherichia coli by the cladoceran Daphnia magna. Bulletin of environmental contamination and toxicology 97:848-854.

Olanrewaju TO, McCarron M, Dooley JS, Arnscheidt J. 2019. Transfer of antibiotic resistance genes between Enterococcus faecalis strains in filter feeding zooplankton Daphnia magna and Daphnia pulex. Science of The Total Environment 659:1168-1175.

Pfenning-Butterworth A, Cooper RO, Cressler CE. 2021. Daily feeding rhythm linked to microbiome composition in two zooplankton species. bioRxiv:2021.2010.2028.466290.

Pommepuy M, Butin M, Derrien A, Gourmelon M, Colwell RR, Cormier M. 1996. Retention of enteropathogenicity by viable but nonculturable Escherichia coli exposed to seawater and sunlight. Applied and environmental microbiology 62:4621-4626. 
bioRxiv preprint doi: https://doi.org/10.1101/2021.12.23.474077; this version posted December 27, 2021. The copyright holder for this preprint (which was not certified by peer review) is the author/funder, who has granted bioRxiv a license to display the preprint in perpetuity. It is made available under aCC-BY-NC-ND 4.0 International license.

Power ML, Littlefield-Wyer J, Gordon DM, Veal DA, Slade MB. 2005. Phenotypic and genotypic characterization of encapsulated Escherichia coli isolated from blooms in two Australian lakes. Environ Microbiol 7:631-640.

Prjibelski A, Antipov D, Meleshko D, Lapidus A, Korobeynikov A. 2020. Using SPAdes de novo assembler. Current protocols in bioinformatics 70:e102.

Quero GM, Fasolato L, Vignaroli C, Luna GM. 2015. Understanding the association of Escherichia coli with diverse macroalgae in the lagoon of Venice. Scientific Reports 5.

RCore Team. 2013. R: A language and environment for statistical computing, Vienna, Austria.

Riva F, Riva V, Eckert EM, Colinas N, Di Cesare A, Borin S, Mapelli F, Crotti E. 2020. An Environmental Escherichia coli Strain Is Naturally Competent to Acquire Exogenous DNA. Frontiers in microbiology 11:2131.

Sabatino R, Di Cesare A, Pasquaroli S, Vignaroli C, Citterio B, Amiri M, Rossi L, Magnani M, Mauro A, Biavasco F. 2015. Adherence and intracellular survival within human macrophages of Enterococcus faecalis isolates from coastal marine sediment. Microbes and Infection 17:660-664.

Salcher MM, Schaefle D, Kaspar M, Neuenschwander SM, Ghai R. 2019. Evolution in action: habitat transition from sediment to the pelagial leads to genome streamlining in Methylophilaceae. The ISME journal 13:2764-2777.

Signoretto C, Burlacchini G, Lleò MdM, Pruzzo C, Zampini M, Pane L, Franzini G, Canepari P. 2004. Adhesion of $<i>$ Enterococcus faecalis $</ i>$ in the Nonculturable State to Plankton Is the Main Mechanism Responsible for Persistence of This Bacterium in both Lake and Seawater. Applied and environmental microbiology 70:6892-6896.

Srinivasan S, Aslan A, Xagoraraki I, Alocilja E, Rose JB. 2011. Escherichia coli, enterococci, and Bacteroides thetaiotaomicron qPCR signals through wastewater and septage treatment. Water research 45:2561-2572. Stepanović S, Vuković D, Hola V, Di Bonaventura G, Djukić S, Cirković I, Ruzicka F. 2007. Quantification of biofilm in microtiter plates: overview of testing conditions and practical recommendations for assessment of biofilm production by staphylococci. Apmis 115:891-899.

Touchon M, Perrin A, de Sousa JAM, Vangchhia B, Burn S, O’Brien CL, Denamur E, Gordon D, Rocha EPC. 2020. Phylogenetic background and habitat drive the genetic diversification of Escherichia coli. PLOS Genetics 16:e1008866.

Urzì C, Brusetti L, Salamone P, Sorlini C, Stackebrandt E, Daffonchio D. 2001. Biodiversity of Geodermatophilaceae isolated from altered stones and monuments in the Mediterranean basin. Environmental microbiology 3:471-479.

Vallenet D, Engelen S, Mornico D, Cruveiller S, Fleury L, Lajus A, Rouy Z, Roche D, Salvignol G, Scarpelli C, et al. 2009. MicroScope: a platform for microbial genome annotation and comparative genomics. Database 2009:bap021.

Versalovic J, Koeuth T, Lupski R. 1991. Distribution of repetitive DNA sequences in eubacteria and application to finerpriting of bacterial enomes. Nucleic Acids Research 19:6823-6831.

Vignaroli C, Luna G, Pasquaroli S, Di Cesare A, Petruzzella R, Paroncini P, Biavasco F. 2013. Epidemic Escherichia coli ST131 and Enterococcus faecium ST17 in coastal marine sediments from an Italian beach. Environmental science \& technology 47:13772-13780.

Vignaroli C, Luna GM, Rinaldi C, Di Cesare A, Danovaro R, Biavasco F. 2012. New Sequence Types and Multidrug Resistance among Pathogenic Escherichia coli Isolates from Coastal Marine Sediments. Applied and environmental microbiology 78:3916-3922.

Walk ST, Alm EW, Calhoun LM, Mladonicky JM, Whittam TS. 2007. Genetic diversity and population structure of Escherichia coli isolated from freshwater beaches. Environ Microbiol 9:2274-2288. Wanjugi P, Harwood VJ. 2013. The influence of predation and competition on the survival of commensal and pathogenic fecal bacteria in aquatic habitats. Environmental microbiology 15:517-526. Wickham H. 2009. ggplot2: elegant graphics for data analysis: Springer Science \& Business Media. Wickham H. 2012. reshape2: Flexibly reshape data: a reboot of the reshape package. R package version 1. Wilke CO. 2020. cowplot: Streamlined Plot Theme and Plot Annotations for 'ggplot2'.

Zotina T, Köster O, Jüttner F. 2003. Photoheterotrophy and light-dependent uptake of organic and organic nitrogenous compounds by Planktothrix rubescens under low irradiance. Freshwater Biology 48:1859-1872. 
bioRxiv preprint doi: https://doi.org/10.1101/2021.12.23.474077; this version posted December 27, 2021. The copyright holder for this preprint (which was not certified by peer review) is the author/funder, who has granted bioRxiv a license to display the preprint in perpetuity. It is made available under aCC-BY-NC-ND 4.0 International license.

\section{3}

